\title{
PENERAPAN PENDEKATAN SUPERVISI AKADEMIK KOLABORATIF UNTUK MENINGKATKAN KOMPETENSI GURU DI SDN TANAH MERAH
}

\section{APPLICATION OF COLLABORATIVE ACADEMIC SUPERVISION APPROACH TO IMPROVE TEACHER COMPETENCY AT TANAH MERAH SDN}

\author{
Stanislaus Sika ${ }^{1}$ \\ SDN Tanah Merah, \\ Desa Talibura, Kec. \\ Talibura Kab. Sikka \\ NTT, Indonesia ${ }^{1}$ \\ sikastanislaus@gmail \\ .com
}

IJI Publication p-ISSN: 2774-1907 e-ISSN: 2774-1915 Vol. 1, No. 3, pp. 180188, Juli 2021

Unit Publikasi Ilmiah Intelektual Madani Indonesia
Abstrak: Tujuan penelitian ini untuk meningkatkan kompetensi profesional guru di SDN Tanah Merah dihasilkan dua hal berikut: (1) Proses supervisi dengan menerapkan pendekatan supervisi kolaboratif secara spesifik terdiri dari tahap pra-supervisi kolaboratif, supervisi kolaboratif dan pasca-supervisi kolaboratif. Proses supervisi dengan menerapkan pendekatan supervisi kolaboratif mengalami perkembangan dari siklus I ke siklus II. Pada tahap pra-supervisi kolaboratif siklus I, curah pendapat tidak berjalan dengan efektif karenakepala sekolah tidak melakukan koordinasi dengan semua guru dan tidak menjelaskan teknis supervisi kolaboratif yang akan dilaksanakan diantaranya mengindentifikasi masalah-masalah krusial ketika guru melaksanakan kinerja profesionalnya, mencatat dan membawanya pada saat curah pendapat dan diskusi bersama kepala sekolah dan guru lainnya. Kemudian pada siklus II, kepala sekolah melakukan koordinasi dengan semua guru dan menjelaskan teknis supervisi kolaboratif yang akan dilaksanakan serta menguatkan dan menegaskan kepada guru untuk menyiapkan kelengkapan terkait kinerja profesionalnya sehingga curah pendapat dan diskusi berjalan dengan tertib dan efektif; (2) Peningkatan kompetensi profesional guru di SDN Tanah Merah dari pra-siklus ke siklus Isebesar 18,18 poin. Rata-rata kompetensi profesional guru pada pra-siklus sebesar 52,27 dengan kriteria kurang dan pada siklus I sebesar 70,45 dengan kriteria cukup. Kompetensi profesional guru juga mengalami peningkatan dari siklus I ke siklus II sebesar 18,19 poin. Rata-rata kompetensi profesional guru pada siklus II sebesar 88,64 dengan kriteria baik. Jadi, dapat disimpulkan bahwa kompetensi profesional guru di SDN Tanah Merah dapat ditingkatkan melalui penerapan pendekatan supervisi kolaboratif.

Kata Kunci : Kompetensi Guru, Supervisi Akademik, Kolaboratif.

Abstract: The purpose of this study to improve the professional competence of teachers at SDN Tanah Merah resulted in the following two things: (1) The supervision process by applying a collaborative supervision approach specifically consisted of collaborative pre-supervision, collaborative supervision and collaborative post-supervision stages. The supervision process by applying a collaborative supervision approach has progressed from cycle I to cycle II. At the stage of collaborative pre-supervision cycle I, brainstorming did not work effectively because the principal did not coordinate with all teachers and did not explain the technical collaborative supervision to be carried out including identifying crucial problems when teachers carried out their professional performance, taking notes and bringing them during brainstorming. and discussions with school principals and other teachers. Then in cycle II, the principal coordinates with all teachers and explains the technical collaborative supervision that will be carried out as well as strengthens and confirms to teachers to prepare completeness related to their professional performance so that brainstorming and discussions run in an orderly and effective manner; (2) Increasing the professional competence of teachers at SDN Tanah Merah from pre-cycle to cycle I by 18.18 points. The average professional competence of teachers in the pre-cycle is 52.27 with less criteria and 70.45 in the first cycle with sufficient criteria. The professional competence of teachers also increased from cycle I to cycle II by 18.19 points. The average professional competence of teachers in the second cycle is 88.64 with good criteria. So, it can be concluded that the professional competence of teachers at SDN Tanah Merah can be improved through the application of a collaborative supervision approach.

Keywords: Teacher Competence, Academic Supervision, Collaborative.

\section{PENDAHULUAN}

Efektivitas

pelaksanaaan kinerja profesional guru sangat bergantung pada kompetensi kepala sekolah dalam melaksanakan tugasnya, diantaranya dalam melakukan supervisi akademik. Untuk melaksanakan supervisi akademik, kepala sekolah

sebagai

supervisor

dan

penanggungjawab kegiatan di sekolah harus mampu menyusun program, melaksanakan, dan melakukan tindak lanjut supervisi akademik di sekolah yang dipimpinnya. Pelaksanaan supervisi akademik yang baik oleh kepala sekolah akan menghasilkan 
kompetensi guru dalam memfasilitasi pembelajaran yang baik pula. Selanjutnya, pembelajaran yang dilaksanakan dengan baik akan berdampak pada peningkatan prestasi siswa. Dengan demikian, keberhasilan siswa dalam pembelajaran sangat bergantung pada kemampuan guru dalam memfasilitasi pembelajaran dan kompetensi kepala sekolah dalam melaksanakan supervisi akademik.

Kompetensi supervisi akademik kepala sekolah terdiri dari tiga aspek yaitu kompetensi dalam menyusun program, melaksanakan, mengevaluasi dan menindaklanjuti temuan-temuan ketika melaksanakan supervisi akademiknya. Program supervisi akademik yang harus disusun oleh seorang kepala sekolah merupakan pedoman atau acuan dalam melaksanakan supervisi akademik. Selain itu, program supervisi akademik juga dapat mengembangkan kemampuan guru dalam mengelola pembelajaran secara efektif. Dari hasil pelaksanaan supervisi akademik, kepala sekolah juga harus mampu merefleksi kinerjanya dan melaksanakan tindak lanjut sebagai umpan balik yang sangat berguna untuk peningkatan kualitas baik bagi siswa, guru, maupun dirinya yang pada akhirnya dapat meningkatkan kualitas pendidikan di sekolahnya.

Berdasarkan hasil refleksi diri yang telah dilakukan oleh peneliti sebagai kepala sekolah, selama ini kepala sekolah melaksanakan tugas supervisi akademiknya dengan menerapkan pendekatan supervisi langsung secara individual, dengan cara mendatangi guru yang sedang bertugas, mengamati kinerjanya dan melakukan penilaian. Pendekatan supervisi individual ini tidak terlalu efektif untuk meningkatkan kompetensi guru dalam melaksanakan tugasnya khususnya yang berkaitan dengan kompetensi profesionalnya. Hasil kajian empirik yang peneliti lakukan terhadap guruguru di SDN Tanah Merah menunjukkan bahwa kompetensi profesional guru masih rendah terutama pada kompetensi guru dalam mengembangkan materi pembelajaran yang diampu secara kreatif. Rata-rata kemampuan guru dalam mengembangkan materi pembelajaran yang diampunya berdasarkanpenilaian kinerja guru terhadap 9 orang guru di SDN Tanah Merah, diperoleh data sebagai berikut:

Tabel 1

Kompetensi Guru dalam Mengembangkan Materi Pembelajaran

\begin{tabular}{clcc}
\hline \multirow{2}{*}{ No. } & \multirow{2}{*}{ Aspek } & \multicolumn{2}{c}{ Rata-rata } \\
& & Skala 4 & Skala 100 \\
\hline 1 & Keterurutan & 2,14 & 53,41 \\
2 & Keberjenjangan & 2,27 & 56,82 \\
3 & Kedalaman & 1,77 & 44,32 \\
4 & Keluasan & 2,18 & 54,55 \\
\multicolumn{2}{c}{ Nilai Rata-rata Keseluruhan } & 2,09 & 52,27 \\
\hline
\end{tabular}

Sumber: Olahan Data Penelitian, 2020

Hasil analisis data pada tabel di atas menunjukkan bahwa kompetensi guru dalam mengembangkan materi pembelajaran yang diampu masih pada kategori sedang yaitu indeks rata-rata 2,09 atau 52,27. Hasil refleksi terhadap temuan tersebut menunjukkan bahwa faktor yang menyebabkan masih rendahnya kompetensi guru tersebut diduga disebabkan oleh faktor internal dan eksternal. Faktor internal yang diduga mempengaruhi rendahya kompetensi profesional guruantara lain: (1) Guru belum memahami teknik pengembangan materi pembelajaran; (2) Guru tidak melakukan analisis materi pembelajaran sebelum mengembangkan bahan ajar atau materi pembelajaran; (3) Kurangnya motivasi diriguru untuk melakukan kinerja profesionalnya dengan baik.

\section{METODE}

Metode penelitian yang digunakan pada penelitian ini adalah metode Penelitian Tindakan Sekolah (PTS) dengan model Kemmis dan Mc. Taggart yang merupakan model pengembangan dari model Kurt Lewin. Dikatakan demikian, karena di dalam suatu siklus terdiri atas empat komponen, 
keempat komponen tersebut, meliputi: (1) perencanaan, (2) aksi/tindakan, (3) observasi, dan (4) refleksi. Setelah suatu siklus selesai diimplementasikan, khususnya sesudah adanya refleksi, kemudian diikuti dengan adanya perencanaan ulang yang dilaksanakan dalam bentuk siklus tersendiri.

Akan tetapi, pada umumnya para peneliti mulai dari fase refleksi awal untuk melakukan studi pendahuluan sebagai dasar dalam merumuskan masalah penelitian. Selanjutnya diikuti perencanaan, tindakan, observasi, dan refleksi.

\section{HASIL DAN DISKUSI}

Penelitian tindakan sekolah ini dilakukan dalam dua siklus. Berikut merupakan deskripsi hasil penelitian tindakan sekolah terkait dengan proses supervisi dengan menerapkan pendekatan supervisi kolaboratif pada siklus I dan Siklus II.

\section{Proses Supervisi Kolaboratif pada Siklus I}

Supervisi kolaboratif pada siklus 1 ini dilaksanakan pada tanggal 3 September sampai dengan 2 November 2020. Pendekatan supervisi kolaboratif pada siklus 1 dilaksanakan dengan menerapkan kesepuluh prinsip pendekatan supervisi kolaboratif yaitu prinsip kolaboratif, kolegial, kemitraan, terbuka dan fleksibel melalui tahapan-tahapan spesifik sebagai berikut:

Tabel 2

Deskripsi Hasil Observasi Proses Supervisi dengan Menerapkan Pendekatan Supervisi Kolaboratif pada Siklus 1

\begin{tabular}{|c|c|c|}
\hline No & $\begin{array}{l}\text { Tahapan } \\
\text { Spesifik }\end{array}$ & Temuan \\
\hline 1 & $\begin{array}{l}\text { Tahap Pra- } \\
\text { Supervisi } \\
\text { Kolaboratif }\end{array}$ & $\begin{array}{l}\text { Seluruh guru tidak membawa daftar } \\
\text { masalah terkait kompetensi profesionalnya } \\
\text { dalam mengembangkan materi } \\
\text { pembelajaran dan bahan ajar, curah } \\
\text { pendapat dan diskusi tidak berjalan } \\
\text { dengan baik, hanya satu orang guru yaitu } \\
\text { G05 yang aktif mencurahkan pendapatnya }\end{array}$ \\
\hline 2 & $\begin{array}{l}\text { Tahap } \\
\text { Pelaksanaan } \\
\text { Supervisi } \\
\text { Kolaboratif }\end{array}$ & $\begin{array}{l}\text { Guru G03 dan G07 tidak menyiapkan } \\
\text { hasil analisis materi pembelajaran yang } \\
\text { telah disusunnya sehingga mengganggu } \\
\text { proses supervisi kolaboratif }\end{array}$ \\
\hline 3 & $\begin{array}{l}\text { Tahap } \\
\text { Pasca- } \\
\text { Supervisi } \\
\text { Kolaboratif }\end{array}$ & $\begin{array}{l}\text { Seluruh guru terlibat dalam proses refleksi } \\
\text { pelaksanaan supervisi kolaboratif dengan } \\
\text { menyampaikan temuan dan } \\
\text { pemecahannya }\end{array}$ \\
\hline
\end{tabular}

Sumber: Olahan Data Penelitian, 2020
Pada siklus I ditemukan beberapa temuan pada tahap spesifik kegiatan supervisi kepala sekolah dengan menerapkan pendekatan supervisi kolaboratif. Hasil refleksi pada siklus I yang telah dilakukan menunjukkan beberapa hal sebagai berikut:

1. Seluruh guru tidak membawa daftar masalah terkait kompetensi profesionalnya dalam mengembangkan materi pembelajaran dan bahan ajar sehingga curah pendapat dan diskusi pada tahap pra-supervisi kolaboratif tidak berjalan dengan baik dibuktikan dengan hanya satu orang guru berkode G05 yang aktif mencurahkan pendapatnya. Temuan ini diduga disebabkan oleh kepala sekolah yang tidak melakukan koordinasi dengan guru untuk mengidentifikasi masalahmasalah krusial pada saat melakukan kinerja profesionalnya dalam mengembangkan materi pembelajaran dan bahan ajar, mencatat dan membawanya pada saat curah pendapat dan diskusi dilakukan (tahap pra-supervisi kolaboratif). Hal ini bertentangan dengan pendapat Glickman (1984) yang menyatakan bahwa tugas supervisi oleh kepala sekolah dalam supervisi kolaboratif adalah mendengarkan dan memperhatikan secara cermat keluhan guru terhadap masalah perbaikan, peningkatan, dan pengembangan kinerjanya. Dalam pendekatan supervisi kolaboratif, kepala sekolah dapat meminta penjelasan guru terhadap hal-hal yang kurang dipahaminya. Selanjutnya, kepala sekolah mendorong guru untuk mengaktualisasikan pemikiran bersama dalam praktik nyata pemecahan masalah yang berkaitan dengan tugas profesional guru. Dikarenakan pada tahapan ini guru tidak melakukan identifikasi masalahmasalah ketika melaksanakan kinerja profesionalnya dalam mengembangkan materi pembelajaran dan bahan ajar, tidak mencatat dan membawanya pada kegiatan pra-supervisi kolaboratif, sehingga bahan 
untuk diskusi dan curah pendapat sangat kurang dan tidak terfokus. Hal ini menyebabkan curah pendapat dan diskusi tidak dapat berjalan dengan baik, sehingga tahap pra-supervisi kolaboratif tidak dapat dilaksanakan secara efektif. Adapun guru yang berkode G05 aktif mencurahkan pendapatnya tetapi masalah yang disampaikannya tidak terfokus pada kompetensi profesional terkait pengembangan materi pembelajaran dan bahan ajar. Berdasarkan hasil analisis data di atas, sebelum melakukan kegiatan supervisi kolaboratif khususnya pada tahap pra-supervisi kolaboratif, kepala sekolah terlebih dahulu melakukan koordinasi dengan semua guru dan menjelaskan teknis supervisi kolaboratif yang akan dilaksanakan diantaranya mengindentifikasi masalah-masalah krusial ketika melaksanakan kinerja profesionalnya, mencatat dan membawanya pada saat curah pendapat dan diskusi bersama kepala sekolah dan guru lainnya.

2. Terdapat dua orang guru dengan kode G03 dan G07 yang tidak menyiapkan hasil analisis materi pembelajaran ketika supervisi kolaboratif dilakukan di sekolah sehingga pelaksanaan supervisi kolaboratif menjadi terganggu. Segiovanni (1987) menyatakan bahwa penilaian kinerja guru dalam mengembangkan materi pembelajaran dan bahan ajar tidak terlepas dari hasil analisis materi pembelajaran yang telah disusunnya. Menurutnya, menilai unjuk kerja guru dalam mengembangkan materi pembelajaran dan bahan ajar merupakan salah satu kegiatan yang tidak bisa dihindarkan dari prosesnya. Kegiatan penilaian kinerja guru dalam mengembangkan materi pembelajaran dan bahan ajar dilakukan terhadap hasil analisis materi pembelajaran yang sebelumnya harus disiapkan oleh guru sebelum melaksanakan kinerja profesionalnya dalam mengembangkan materi pembelajaran dan bahan ajar. Nolan (2011) menyatakan bahwa supervisi akademik dapat berjalan dengan baik jika guru menyiapkan perlengkapan dan instrumen yang dibutuhkan. Instrumen supervisi akademik yang tidak disiapkan oleh guru dikarenakan pada tahap prasupervisi kolaboratif, kepala sekolah tidak menegaskan atau menguatkan bahwa pada tahap supervisi kolaboratif, guru harus menyiapkan perlengkapan dan instrumen supervisi akademik. Berdasarkan hasil analisis data di atas, sebelum melakukan kegiatan supervisi kolaboratif, kepala sekolah seharusnya menguatkan dan menegaskan kepada guru untuk menyiapkan kelengkapan diantaranya instrumen supervisi akademik pada tahap pra-supervisi kolaboratif.

Berdasarkan hasil refleksi di atas, peneliti merekomendasikan pelaksanaan supervisi dengan menerapkan pendekatan supervisi kolaboratif untuk siklus 2 sebagai berikut:

1. Pada tahap pra-supervisi kolaboratif, kepala sekolahharus terlebih dahulu melakukan koordinasi dengan semua guru dan menjelaskan teknis supervisi kolaboratif yang akan dilaksanakan diantaranya mengindentifikasi masalahmasalah krusial ketika melaksanakan kinerja profesionalnya, mencatat dan membawanya pada saat curah pendapat dan diskusi bersama kepala sekolah dan guru lainnya.

2. Pada tahap pelaksanaan supervisi kolaboratif, kepala sekolah harus menguatkan dan menegaskan kepada guru untuk menyiapkan kelengkapan untuk melaksanakan kinerja profesionalnya pada tahap pra-supervisi kolaboratif.

\section{Proses Supervisi Kolaboratif pada Siklus II}

Supervisi kolaboratif pada siklus II ini dilaksanakan pada tanggal 10 sampai dengan 
24 November 2020. Pendekatan supervisi kolaboratif pada siklus II dilaksanakan berdasarkan rekomendasi-rekomendasi pada siklus I dengan menerapkan kesepuluh prinsip pendekatan supervisi kolaboratif yaitu prinsip kolaboratif, kolegial, kemitraan, terbuka dan fleksibel melalui tahapantahapan spesifik sebagai berikut:

Tabel 3

Deskripsi Hasil Observasi Proses Supervisi dengan Menerapkan Pendekatan Supervisi Kolaboratif pada Siklus II

\begin{tabular}{|c|c|c|}
\hline No & $\begin{array}{l}\text { Tahapan } \\
\text { Spesifik }\end{array}$ & Temuan \\
\hline 1 & $\begin{array}{l}\text { Tahap Pra- } \\
\text { Supervisi } \\
\text { Kolaboratif }\end{array}$ & $\begin{array}{l}\text { Curah pendapat dan diskusi } \\
\text { berjalan dengan baik, seluruhguru } \\
\text { aktif berdiskusi dan mencurahkan } \\
\text { pendapatnya }\end{array}$ \\
\hline 2 & $\begin{array}{l}\text { Tahap } \\
\text { Pelaksanaan } \\
\text { Supervisi } \\
\text { Kolaboratif }\end{array}$ & $\begin{array}{l}\text { Pelaksanaan supervisi kolaboratif } \\
\text { berjalan dengan efektif, guru } \\
\text { mampu menerapkan solusi-solusi } \\
\text { dari masalah yang teridentifikasi } \\
\text { sebelumnya sebagai hasil curah } \\
\text { pendapat dan diskusi dengan guru } \\
\text { lain dan kepala sekolah pada tahap } \\
\text { pra-supervisi kolaboratif. }\end{array}$ \\
\hline 3 & $\begin{array}{l}\text { Tahap Pasca- } \\
\text { Supervisi } \\
\text { Kolaboratif }\end{array}$ & $\begin{array}{l}\text { Seluruh guru terlibat dalam proses } \\
\text { refleksi }\end{array}$ \\
\hline
\end{tabular}

Sumber: Olahan Data Penelitian, 2020

Pada siklus II ini tidak ditemukan lagi temuan-temuan negatif, dan pelaksanaan supervisi kolaboratif sudah sesuai dengan tahapan-tahapan spesifik supervisi kolaboratif. Temuan-temuan positif pada tahap spesifik supervisi dengan menerapkan pendekatan supervisi kolaboratif. Hasil refleksi pada siklus II yang telah dilakukan menunjukkan beberapa hal sebagai berikut:

1. Curah pendapat dan diskusi berjalan dengan baik dan seluruh guru aktif berdiskusi dan mencurahkan pendapatnya dikarenakan pada tahap pra-supervisi kolaboratif, kepala sekolah terlebih dahulu melakukan koordinasi dengan semua guru dan menjelaskan teknis supervisi kolaboratif yang akan dilaksanakan diantaranya mengindentifikasi masalahmasalah krusial ketika melaksanakan kinerja profesionalnya, mencatat dan membawanya pada saat curah pendapat dan diskusi bersama kepala sekolah dan guru lainnya.

1. Pelaksanaan supervisi kolaboratif berjalan dengan efektif dan guru mampu menerapkan solusi-solusi dari masalah yang teridentifikasi sebelumnya sebagai hasil curah pendapat dan diskusi dengan guru lain dan kepala sekolah pada tahap pra-supervisi kolaboratif. Hal ini dikarenakan bahwa proses supervisi kolaboratif telah menerapkan prinsipprinsipnya yaitu kolaboratif, kolegial, kemitraan, terbuka dan fleksibel. Selain itu, Pada akhir tahap pra-supervisi kolaboratif, kepala sekolah menguatkan dan menegaskan kepada guru untuk menyiapkan kelengkapan dalam melaksanakan kinerja profesionalnya berupa hasil analisis materi pembelajaran.

2. Seluruh guru terlibat dalam proses refleksi pada tahap pasca-supervisi kolaboratif dikarenakan kepala sekolah telah koordinatif dengan guru dan telah berhasil memotivasi guru untuk saling belajar.

Berdasarkan hasil refleksi di atas, peneliti merekomendasikan pelaksanaan supervisi dengan menerapkan pendekatan supervisi kolaboratif sebagai berikut:

1. Pada tahap pra-supervisi kolaboratif, kepala sekolah terlebih dahulu melakukan koordinasi dengan semua guru dan menjelaskan teknis supervisi kolaboratif yang akan dilaksanakan diantaranya mengindentifikasi masalah-masalah krusial ketika melaksanakan kinerja profesionalnya, mencatat dan membawanya pada saat curah pendapat dan diskusi bersama kepala sekolah dan guru lainnya.

2. Pada tahap supervisi kolaboratif, kepala sekolah harus menerapkan prinsip-prinsip pendekatan supervisi kolaboratif yaitu prinsip kolaboratif, kolegial, kemitraan, terbukadan fleksibel. Serta untuk keberhasilan pelaksanaan kinerja profesionalnya, kepala sekolah harus 
menguatkan dan menegaskan kepada guru untuk menyiapkan kelengkapan berupa hasil analisis materi pembelajaran pada tahap pra-supervisi kolaboratif.

3. Pada tahap pasca-supervisi kolaboratif, kepala sekolah harus koordinatif dengan guru dan memotivasi guru untuk saling belajar.

Berikut merupakan perkembangan temuan selama proses supervisi dengan menerapkan pendekatan supervisi kolaboratif dari siklus I ke siklus II.

\section{Tabel 4}

Perkembangan Temuan selama Proses Supervisi dengan Menerapkan Pendekatan Supervisi Kolaboratif

\begin{tabular}{|c|c|c|}
\hline Tahapan & Siklus I & Siklus II \\
\hline $\begin{array}{l}\text { Pra- } \\
\text { Supervisi } \\
\text { Kolaboratif }\end{array}$ & $\begin{array}{l}\text { Seluruh guru tidak } \\
\text { membawa daftar } \\
\text { masalah terkait kinerja } \\
\text { profesionalnya, curah } \\
\text { pendapat dan diskusi } \\
\text { tidak berjalan dengan } \\
\text { baik, hanya satu guru } \\
\text { yaitu G05 yang aktif } \\
\text { mencurahkan } \\
\text { pendapatnya }\end{array}$ & $\begin{array}{l}\text { Curah pendapat } \\
\text { dan diskusi } \\
\text { berjalan dengan } \\
\text { baik, seluruh } \\
\text { guru aktif } \\
\text { berdiskusi dan } \\
\text { mencurahkan } \\
\text { pendapatnya }\end{array}$ \\
\hline $\begin{array}{l}\text { Pelaksanaan } \\
\text { Supervisi } \\
\text { Kolaboratif }\end{array}$ & $\begin{array}{l}\text { Guru G03 dan G07 } \\
\text { tidak menyiapkan } \\
\text { kelengkapan berupa } \\
\text { hasil analisis materi } \\
\text { pembelajaran } \\
\text { sehingga mengganggu } \\
\text { proses supervisi } \\
\text { kolaboratif }\end{array}$ & $\begin{array}{l}\text { Pelaksanaan } \\
\text { supervisi } \\
\text { kolaboratif } \\
\text { berjalan dengan } \\
\text { efektif, guru } \\
\text { mampu } \\
\text { menerapkan } \\
\text { solusi-solusi dari } \\
\text { masalah yang } \\
\text { teridentifikasi } \\
\text { sebelumnya } \\
\text { sebagai hasil } \\
\text { curah pendapat } \\
\text { dan diskusi } \\
\text { dengan guru lain } \\
\text { dan kepala } \\
\text { sekolah pada } \\
\text { tahap pra- } \\
\text { supervisi } \\
\text { kolaboratif. }\end{array}$ \\
\hline $\begin{array}{l}\text { Pasca- } \\
\text { Supervisi } \\
\text { Kolaboratif }\end{array}$ & $\begin{array}{l}\text { Seluruh guru terlibat } \\
\text { dalam proses refleksi } \\
\text { pelaksanaan supervisi } \\
\text { kolaboratif dengan } \\
\text { menyampaikan } \\
\text { temuan dan } \\
\text { pemecahannya }\end{array}$ & $\begin{array}{l}\text { Seluruh guru } \\
\text { terlibat dalam } \\
\text { proses refleksi }\end{array}$ \\
\hline
\end{tabular}

Sumber: Olahan Data Penelitian, 2020

Berdasarkan temuan tersebut, tabel 5 berikut merupakan perkembangan proses supervisi kolaboratif dari siklus I ke siklus II yang mengalami perkembangan terutama pada tahap pra-supervisi kolaboratif.

Tabel 5

Perkembangan Proses Supervisi dengan Menerapkan Pendekatan Supervisi Kolaboratif

\begin{tabular}{|c|c|c|}
\hline Tahapan & Siklus 1 & Siklus 2 \\
\hline $\begin{array}{l}\text { Pra- } \\
\text { Supervisi } \\
\text { Kolaboratif }\end{array}$ & $\begin{array}{l}\text { Kepala sekolah } \\
\text { bersama semua } \\
\text { guru } \\
\text { melaksanakan } \\
\text { curah pendapat } \\
\text { dan diskusi } \\
\text { difasilitasi oleh } \\
\text { kepala sekolah } \\
\text { tentang masalah- } \\
\text { masalah krusial } \\
\text { guru dalam } \\
\text { melaksanakan } \\
\text { kinerja } \\
\text { profesionalnya. }\end{array}$ & $\begin{array}{l}\text { Kepala sekolah } \\
\text { terlebih dahulu } \\
\text { melakukan koordinasi } \\
\text { dengan semua guru } \\
\text { dan menjelaskan } \\
\text { teknis supervisi } \\
\text { kolaboratif yang akan } \\
\text { dilaksanakan } \\
\text { diantaranya } \\
\text { mengindentifikasi } \\
\text { masalah-masalah } \\
\text { krusial ketika } \\
\text { melaksanakan kinerja } \\
\text { profesionalnya, } \\
\text { mencatat dan } \\
\text { membawanya pada } \\
\text { saat curah pendapat } \\
\text { dan diskusi bersama } \\
\text { kepala sekolah dan } \\
\text { guru lainnya. } \\
\text { Selanjutnya, kepala } \\
\text { sekolah bersama } \\
\text { semua guru } \\
\text { melaksanakan curah } \\
\text { pendapat dan diskusi } \\
\text { difasilitasi oleh kepala } \\
\text { sekolah tentang } \\
\text { masalah-masalah } \\
\text { krusial yang } \\
\text { teridentifikasi oleh } \\
\text { guru dalam } \\
\text { melaksanakan kinerja } \\
\text { profesionalnya. Pada } \\
\text { akhir tahap pra- } \\
\text { supervisi kolaboratif, } \\
\text { kepala sekolah } \\
\text { menguatkan dan } \\
\text { menegaskan kepada } \\
\text { guru untuk } \\
\text { menyiapkan } \\
\text { kelengkapan } \\
\text { diantaranya hasil } \\
\text { analisis materi } \\
\text { pembelajaran. }\end{array}$ \\
\hline
\end{tabular}

Sumber: Olahan Data Penelitian, 2020

\section{Kompetensi Profesional Guru pada Siklus I}

Kompetensi profesional guru ini terdiri dari kemampuannya dalam mengembangkan materi pembelajaran dan bahan ajar. Kompetensi guru dalam melaksanakan kinerja profesionalnya diamati dan diukur menggunakan lembar observasi kinerja profesional guru dalam mengembangkan materi pembelajaran dan bahan ajar. Berikut merupakan rata-rata kompetensi profesional 
guru di SDN Tanah Merah yang diukur dan diamati terhadap 9 guru.

\section{Grafik 1}

Rata-rataKompetensi Profesional Guru dalam Mengembangkan Materi Pembelajaranpada Siklus I

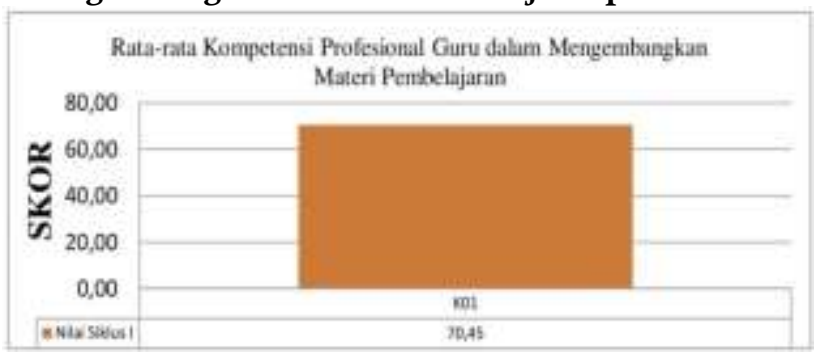

Pada grafik 1 di atas terlihat skor rataratakompetensi profesional guru dalam mengembangkan materi pembelajaran dan bahan ajar sebesar 70,45 dengan kriteria cukup. Hal ini menunjukkan bahwa kemampuan guru dalam mengembangkan materi pembelajaran dan bahan ajar setelah diterapkan pendekatan supervisi kolaboratif sudah cukup baik. Berbeda dengan sebelum diterapkan pendekatan supervisi kolaboratif, rata-rata kompetensi guru dalam mengembangkan materi pembelajaran dan bahan ajar sebesar 52,27 dengan kriteria kurang. Hal ini menunjukkan bahwa pendekatan supervisi kolaboratif dapat meningkatkan kompetensi profesional guru dalam mengembangkan materi pembelajaran dan bahan ajar.

\section{Kompetensi Profesional Guru pada Siklus II}

Seperti halnya pada siklus I, kompetensi profesional guru yang diukur adalah kemampuan guru dalam mengembangkan materi pembelajaran dan bahan ajar. Kompetensi profesional guru ini diamati dan diukur menggunakan lembar observasi kinerja profesional guru dalam mengembangkan materi pembelajaran dan bahan ajar. Berikut merupakan rataratakompetensi profesionalguru di SDN Tanah Merah yang diukur dan diamati terhadap 9 guru.
Grafik 2

Rata-rata Kompetensi Profesional Guru dalam Mengembangkan Materi Pembelajaranpada Siklus II

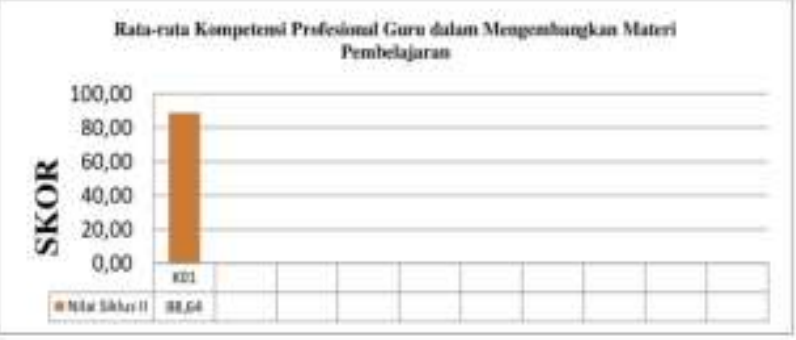

Pada grafik 2 di atas terlihat bahwa skor rata-rata kompetensi profesional guru dalam mengembangkan materi pembelajaran dan bahan ajar sebesar 88,64 dengan kriteria baik. Hal ini menunjukkan bahwa kemampuan guru dalam mengembangkan materi pembelajaran dan bahan ajarpada siklus IIsetelah diterapkan pendekatan supervisi kolaboratif sudah baik. Berbeda dengan siklus I, rata-rata kompetensi profesional guru dalam mengembangkan materi pembelajaran dan bahan ajar sebesar 70,45 dengan kriteria cukup baik. Hal ini menunjukkan bahwa pendekatan supervisi kolaboratif dapat meningkatkan kompetensi profesional guru dalam mengembangkan materi pembelajaran dan bahan ajar.

Kompetensi profesional guru mengalami peningkatan dari pra-siklus, siklus I sampai dengan siklus II. Tabel 6 dan grafik 3 berikut merupakan peningkatan kompetensi profesional guru dari sebelum dilakukan tindakan (pra-siklus) sampai dengan setelah diterapkan tindakan berupa pendekatan supervisi kolaboratif (siklus I dan II).

Tabel 6

Peningkatan Kompetensi Profesional Guru

\begin{tabular}{cccc} 
Kompetensi & Pra-siklus & Siklus 1 & Siklus 2 \\
\hline Rata-rata & 52,27 & 70,45 & 88,64 \\
\hline Kriteria & Kurang & Cukup & Baik
\end{tabular}

Sumber: Olahan Data Penelitian, 2020 
Grafik 3

Peningkatan Kompetensi Profesional Guru

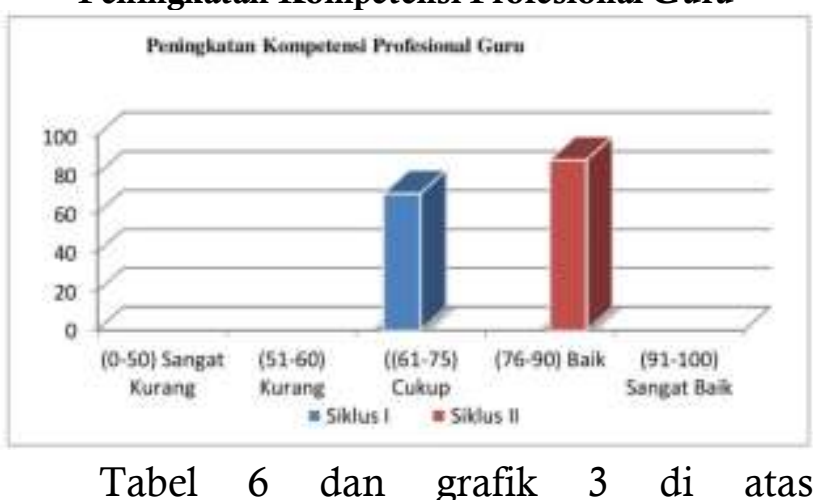

menunjukkan bahwa kompetensi profesional guru mengalami peningkatan dari pra-siklus ke siklus I dan dari siklus I ke siklus II. Hal ini diduga bahwa pendekatan supervisi kolaboratif telah dilaksanakan secara efektif selamat proses supervisi baik pada tahap prapelaksanaan, dan pasca-supervisi kolaboratif.

\section{KESIMPULAN}

Berdasarkan pembahasan dalam penelitian mengenai penerapan pendekatan supervisi kolaboratif untuk meningkatkan kompetensi profesional guru di SDN Tanah Merah dapat ditarik beberapa simpulan sebagai berikut:

1. Proses supervisi dengan menerapkan pendekatan supervisi kolaboratif secara spesifik terdiri dari tahap pra-supervisi kolaboratif, supervisi kolaboratif dan pasca-supervisi kolaboratif. Proses supervisi dengan menerapkan pendekatan supervisi kolaboratif mengalami perkembangan dari siklus I ke siklus II. Pada tahap pra-supervisi kolaboratif siklus I, curah pendapat tidak berjalan dengan efektif karenakepala sekolah tidakmelakukan koordinasi dengan semua guru dan tidak menjelaskan teknis supervisi kolaboratif yang akan dilaksanakan diantaranya mengindentifikasi masalah-masalah krusial ketika guru melaksanakan kinerja profesionalnya, mencatat dan membawanya pada saat curah pendapat dan diskusi bersama kepala sekolah dan guru lainnya. Kemudian pada siklus II, kepala sekolah melakukan koordinasi dengan semua guru dan menjelaskan teknis supervisi kolaboratif yang akan dilaksanakan serta menguatkan dan menegaskan kepada guru untuk menyiapkan kelengkapan terkait kinerja profesionalnya sehingga curah pendapat dan diskusi berjalan dengan tertib dan efektif. Pada tahap supervisi kolaboratif siklus I, proses supervisi kolaboratif terhambat karena guru tidak membawa kelengkapan terkait kinerja profesionalnya, sedangkan pada siklus II mereka membawa semua kelengkapan sehingga pelaksanaan supervisi kolaboratif berjalan dengan tertib. Pada tahap pasca-supervisi kolaboratif, kepala sekolah tidak koordinatif dengan semua guru dan tidak berhasil memotivasi guru untuk saling belajar. Sedangkan pada siklus II, kepala sekolah mulai koordinatif dengan semua dan berhasil memotivasi guru untuk saling belajar.

2. Peningkatan kompetensi profesional guru di SDN Tanah Merah dari pra-siklus ke siklus Isebesar 18,18 poin. Rata-rata kompetensi profesional gurupada prasiklus sebesar 52,27 dengan kriteria kurang dan pada siklus I sebesar 70,45 dengan kriteria cukup. Kompetensi profesional guru juga mengalami peningkatan dari siklus I ke siklus II sebesar 18,19 poin. Rata-rata kompetensi profesional guru pada siklus II sebesar 88,64 dengan kriteria baik. Jadi, dapat disimpulkan bahwa kompetensi profesional guru di SDN Tanah Merah dapat ditingkatkan melalui penerapan pendekatan supervisi kolaboratif.

\section{REFERENSI}

Alfonso, RJ., Firth, G.R., dan Neville, R.F. (1981). Instructional Supervision, A Behavior System. Boston: Allyn and Bacon, Inc. 
Ali Mohamad, (1987). Pengantar Statistik. Bandung: Alfabeta

Danim, Sudarwan. (2006). Visi Baru Manajemen Sekolah. Jakarta: Bumi Aksara.

Departemen Pendidikan dan Kebudayaan RI. (1982). Alat Penilaian Kemampuan Guru: Buku I. Jakarta: Proyek Pengembangan Pendidikan Guru.

(1982). Panduan Umum Alat

Penilaian Kemampuan Guru. Jakarta:

Proyek Pengembangan Pendidikan Guru.

(1996). Pedoman Kerja Pelaksanaan

Supervisi, Jakarta: Depdikbud.

. (1996). Jabatan Fungsional Kepala

Sekolah dan Angka Kreditnya. Jakarta: Depdikbud.

(1997). Pedoman Pembinaan

Profesional Guru Sekolah Dasar. Jakarta:

Direktorat Pendidikan Dasar. . (1997). Pedoman Pengelolaan Gugus

Sekolah: Jakarta: Proyek Peningkatan

Mutu Sekolah Dasar, TK dan SLB. -1998. Petunjuk Teknis Pelaksanaan

Jabatan Fungsional Pengawas

Sekolah dan Angka Kreditnya, Jakarta:

Depdikbud.

(2003). Pedoman Supervisi

Pengajaran. Jakarta: Ditjen Dikdasmen.

Direktorat Tenaga Pendidik - Dirjen PMPTK

- Depdiknas RI. (2007). Supervisi Akademik dalam Peningkatan

Profesionalisme Guru, Jakarta.

Direktorat Tenaga Pendidik - Dirjen PMPTK

- Depdiknas RI. (2008). Metode dan

Teknik Supervisi, Jakarta.

Direktorat Pembinaan Pendidik dan Tenaga

Kependidikan Pendidikan Dasar -

Direktorat Jenderal Pendidikan Dasar

Kementerian Pendidikan dan

Kebudayaan. (2014). Supervisi

Pembelajaran. Bahan Materi Bimbingan

Teknis Penguatan Kepala Sekolah, Jakarta.
Glickman, C.D. (1995). Supervision of Instruction. Boston: Allyn And Bacon Inc.

Gwynn, J.M. (1961). Theory and Practice of Supervision. New York: Dodd, Mead \& Company.

Peraturan Menteri Pendidikan Nasional No.

13 tahun 2007 tentang Standar Kompetensi Kepala Sekolah/Madrasah, Jakarta.

Mansur, S. (2018). Pengaruh Pendekatan Jelajah Alam Sekitar (JAS) Terhadap Hasil Belajar Siswa Pada Materi Klasifikasi Mahluk Hidup di SMPK Binawirawan Maumere. Uhamka. Bioeduscience. 2 (1): 74-80. DOI: 10.29405/j.bes/74-80121314

Peraturan Menteri Pendidikan Nasional No. 41 tahun 2007 tentang Standar Proses Jakarta.

Pidarta, Made. (1992). Pemikiran Tentang Supervisi Pendidikan. Jakarta: Bumi Aksara.

Purwadarminta. (2003). Kamus Umum Bahasa Indonesia, Balai Pustaka Jakata.

Purwanto, Ngalim. (2003). Administrasi dan Supervisi Pendidikan. Bandung: Rosdakarya

Pusat Pengembangan Tenaga Kependidikan Badan PSDMP \& $\mathrm{K}$ dan PMP Kementerian Pendidikan dan Kebudayaan. (2012). Supervisi Akademik. Bahan Pembelajaran UtamaPengembangan Keprofesian Berkelanjutan Tingkat I Kepala Sekolah Dasar/Madrasah Ibtidaiyah. Jakarta.

Sergiovanni, T.J. (1987). The Principalship, A Reflective Practice Perspective. Boston: Allyn and Bacon.

Sergiovanni, T.J. dan R.J. Starrat. (1979). Supervision: Human Perspective. New York: McGraw-Hill Book Company.

Setya AP, 12 Februari 2012, Supervisi Pendidikan, FIP - UNY. 